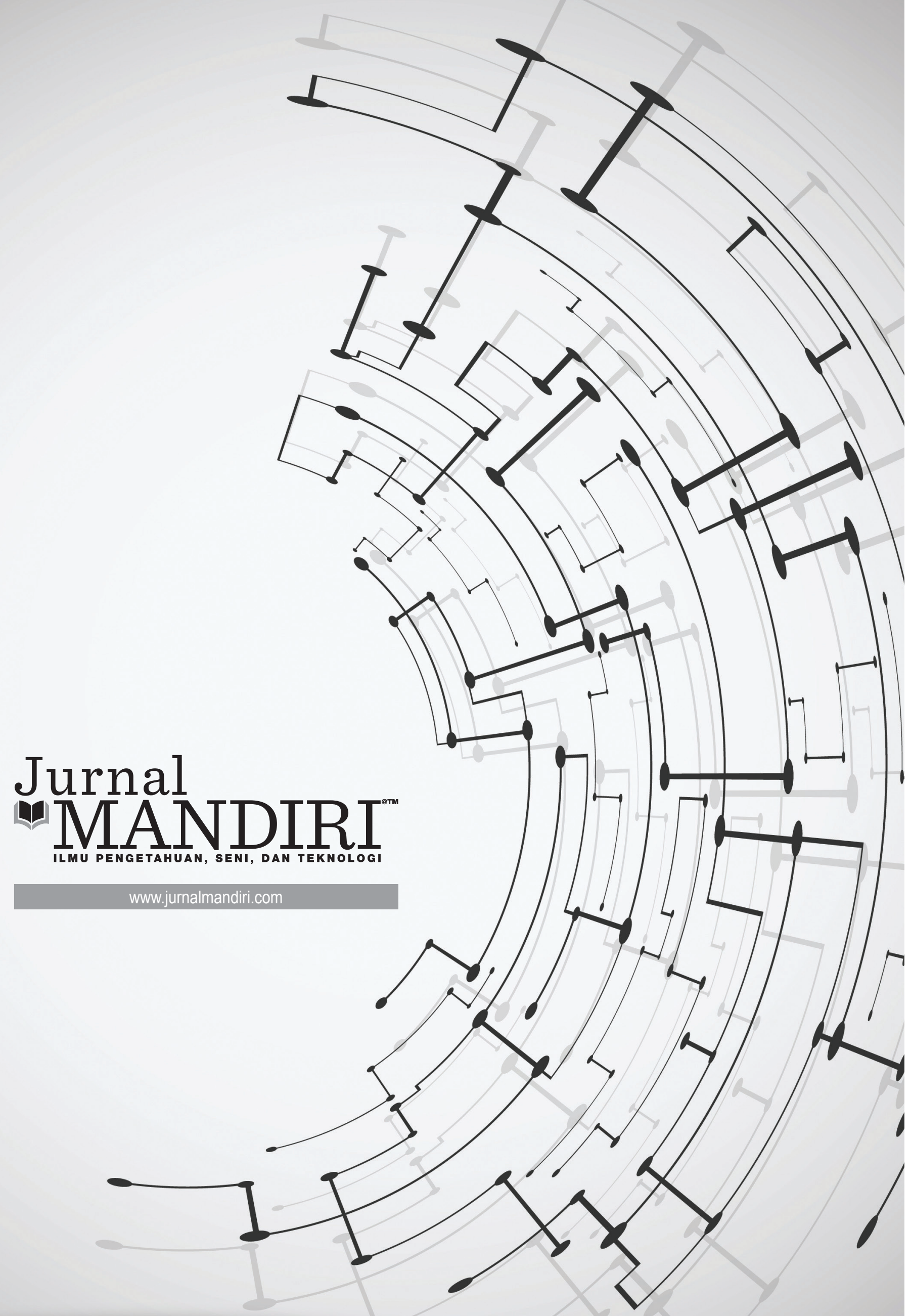


ISSN : 2580-3220, E-ISSN : 2580-4588

J. Mandiri., Vol. 1, No. 2, Desember 2017 (146 - 169)

(C)2017 Lembaga Kajian Demokrasi

dan Pemberdayaan Masyarakat (LKD-PM)

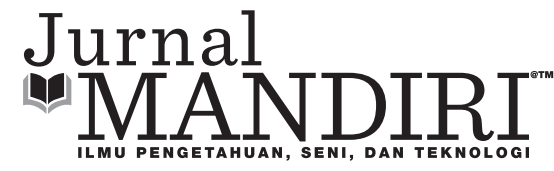

\title{
PENGARUH GAYA KEPEMIMPINAN DAN MOTIVASI TERHADAP KINERJA KARYAWAN (STUDI PADA PT NIKO RESOURCES INDONESIA LTD)
}

\author{
Paeno \\ Universitas Pamulang \\ eno.paeno59@gmail.com,paeno@aei-1.com
}

\begin{abstract}
ABSTRAK
Tujuan dari penelitian ini adalah untuk mengetahui gaya kepemimpinan berpengaruh terhadap di PT Niko Resources Indonesia Ltd, mengetahui motivasi berpengaruh terhadap kinerja karyawan di PT Niko Resources Indonesia Ltd dan mengetahui seberapa besar pengaruh gaya kepemimpinan dan motivasi terhadap kinerja karyawan pada PT Niko Resources Indonesia Ltd. Dalam penelitian ini, penulis menggunakan metode penelitian yang digunakan menggunakan metode Survei Eksplanatori/ eksplanatif/deskriftif korelasional yang bersifat meneliti hubungan antara variabel-variabel yang diteliti, sehingga akan diketahui seberapa besar pengaruh gaya kepemimpinan dan motivasi berpengaruh secara bersama-sama terhadap kinerja karyawan di lingkungan PT Niko Resources Indonesia Ltd. Metode penelitian ini dipilih terutama karena terbatasnya waktu, biaya dan tenaga yang penulis miliki, sehingga masalah ini penulis berharap dapat meneliti aspek-aspek spesifik dari suatu keadaan sosial secara mendalam, dalam hal ini adalah aspek pengaruh gaya kepemimpinan dan motivasi berpengaruh secara bersama-sama terhadap kinerja karyawan. Hasil penelitian menunjukkan bahwa Gaya Kepemimpinan berpengaruh signifikan terhadap kinerja karyawan sebesar 38.3\%, sisanya 61.7\% dipengaruhi oleh factor lain. Motivasi berpengaruh signfiikan terhadap kinerja karyawan sebesar 32.2\% dan sisanya 67.8\% dipengaruhi factor lain. Gaya Kepemimpinan dan motivasi secara bersama-sama mempunyai kontribusi atau pengaruh yang postif terhadap kinerja karyawan sebesar $45.1 \%$ dan selebihnya $54.9 \%$ dipengaruhi oleh variabel lain yang tidak diteliti dalam penelitian ini. nilai Fhitung lebih besar dari Ftabel sebesar 44,392> 3,08 dengan nilai signifikansi 0,000 $<0,05$, maka berarti h0 ditolak dan ha diterima, hal ini menunjukan bahwa variabel gaya kepemimpinan dan motivasi secara bersama-sama berpengaruh positif dan signifikan terhadap kinerja karyawan. Sedangkan persamaan regresi berganda adalah. $\hat{\mathrm{Y}}=13.21+0.357 \mathrm{X} 1+0.391 \mathrm{X} 2$
\end{abstract}

Kata kunci: Kepemimpinan, Motivasi dan Kinerja

\section{PENDAHULUAN}

\section{Latar Belakang}

Sumber daya manusia adalah faktor krusial dan strategis dalam menentukan keberhasilan pelaksanaan dari fungsi-fungsi perusahaan seperti perencanaan, pengorganisasian, ma- najemen, kepemimpinan, pengendalian dan pengawasan, produktivitas kerja, perancangan pekerjaan, pelatihan, pengembangan, penempatan secara efektif dan efisien. SDM perlu dikelola secara baik.

Belajar merupakan proses untuk menge- 
nali dan memahami diri sendiri (self awareness), lingkungan (environment and society awareness), dan interaksi keduanya (relationship awareness). Organisasi menjadi cepat beradaptasi terhadap perubahan lingkungan dan siap untuk berkompetisi, pekerja berbasis pengetahuan (knowledge-based worker) yang merupakan dasar inovasi dan kreasi anggota organisasi, akan meningkatkan nilai organisasi dengan cara membangun manusia pembelajar dalam organisasi, pembelajaran organisasi memungkinkan organisasi mengubah informasi menjadi pengetahuan yang berharga (valued knowledge), yang akan meningkatkan kemampuan organisasi.

Sumber daya manusia adalah aset yang paling utama dalam mencapai tujuan organisasi, keberhasilan organisasi hanya dapat dicapai jika kebijaksanaan pegawai, prosedur, strategi, proses bisnis, iklim, budaya kerja, nilai-nilai, perilaku organisasi terintegrasi dengan baik. Fungsi esensial dari manajemen sumber daya manusia adalah memastikan agar organisasi dapat mencapai tujuan strategis dengan memiliki sumber daya manusia yang dapat diandalkan memenuhi kebutuhan organisasi secara kuantitas maupun kualitas, kompeten dan menghasilkan kinerja yang efektif hingga superior pada jabatan dan peranan masing-masing serta berkontribusi optimal dalam memajukan organisasi.

Menurut Hasibuan (2011:1) manajemen sumber daya manusia merupakan alat untuk mencapai tujuan yang diinginkan. Manajemen yang baik akan memudahkan terwujudnya tujuan perusahaan, karyawan, dan masyarakat. Dengan manajemen, daya guna dan hasil guna unsur-unsur manajemen akan dapat ditingkatkan.

Manajemen adalah ilmu atau sekumpulan pengetahuan yang sistematis, telah dikumpulkan dan di terima secara umum dengan suatu objek dan seni atau suatu kreativitas, pribadi yang kuat dan disertai keterampilan mengatur, memanfaatkan SDM dan sumber daya lainnya secara efektif dan efisien untuk mencapai suatu tujuan tertentu (S.P. Hasibuan, 2008:50).

Manajemen merupakan suatu ilmu dan seni, mengapa disebut demikian, sebab diantara keduanya tidak dapat di pisahkan. Manajemen di sebut sebagai ilmu pengetahuan, karena telah dipelajari sejak lama, dan telah diorganisasikan menjadi suatu teori. Hal ini dikarenakan di dalamnya menjelaskan tentang gejalagejala manajemen, gejala-gejala ini lalu di teliti dengan menggunakan metode ilmiah yang di rumuskan dalam bentuk prinsip-prinsip yang di wujudkan dalam bentuk suatu teori.

Sedangkan manajemen di sebut sebagai seni, di sini memandang bahwa di dalam mencapai suatu tujuan diperlukan kerja sama dengan orang lain, misalkan bagaimnan cara memerintahkan pada orang lain agar mau bekerja sama. Pada hakekatnya kegiatan manusia pada umumnya adalah managing (mengatur) untuk mengatur di sini diprlukan suatu seni, bagaimana orang lain memerlukan pekerjaan untuk mencapai tujuan bersama.

Manajemen di sebut sebagai suatu proses, pengertian ini dapat di lihat dari pengertian menurut :

1. Encyclopedia of the social science (Ensiklopedia dari Ilmu sosial ) yaitu suatu proses dimana pelaksanaan suatu tujuan tertetu dilaksanakan dan diawasi.

2. Haiman, manajemen yaitu fungsi untuk mencapai suatu tujuan melalui kegiatan orang lain, mengawasi usaha-usaha yang dilakukan individu untuk mencapai tujuan.

3. Georgy R. Terry, yaitu cara pencapaian tujuan yang telah ditentukan terlebih dahulu dengan melalui kegiatan orang lain.

Dari devinisi di atas dapat ditarik kesimpulan bahwa manajemen yaitu koordinasi semua sumber daya melalui proses perencanaan, pengorganisasian, penetapan tenaga kerja, pengarahan dan pengawasan untuk mencapai tujuan yang telah di tetapkan terlebih dahulu. Dan manajemen dikatakan sebagai kolektivitas yaitu, merupakan suatu kumpulan dari orang- 
orang yang bekerja sama untuk mencapai suatu tujuan bersama. Kolektivitas atau kumpulan orang-orang inilah yang disebut dengan manajemen, sedang orang yang bertanggung jawab terhadap terlaksananya suatu tujuan atau berjalannya aktivitas manajemen tersebut disebut Manajer.

Manajemen selalu memiliki tujuan yang ditetapkan lebih dulu sebelum kegiatan dilakukan. Tujuan tersebut merupakan sasaran yang hendak dicapai melalui kegiatan yang diatur manajemen (Kartonegoro, 2003:3).

Menurut George Terry (2002:34) Manajemen ini terdiri dari 6 unsur (6M), yaitu: Man, Money, Method, Material, Machine dan Market.

Manusia (Man), dimana aktivitas yang harus dilakukan mencapai tujuan (planning, organizing, directing dan controlling) tidak akan tercapai tanpa adanya manusia.

Uang (Money), untuk melakukan berbagai aktivitas manajemen diperlukan uang, seperti upah atau gaji karyawan. Pembelian faktor produksi dan lain sebagainya. Uang harus digunakan sedemikian rupa agar tujuan yang ingin dicapai, bila dinilai dengan uang lebih besar dari uang atau biaya yang dikeluarkan untuk mencapai tujuan tersebut.

Bahan-bahan (Material), dalam proses pelaksanaan kegiatan dalam tingkat teknologi sekarang ini material bukan saja sebagai pembantu bagi mesin dan mesin telah berubah kedudukannya malahan sebagai penggati itu manusia.

Cara pelaksanaan (Method), untuk melakukan kegiatan-kegiatan secara berdaya guna dan berhasil guna, maka manusia dihadapkan pada berbagai alternatif pelaksanaan (metode).

Pasar (Market), tanpa adanya pasar bagi hasil produksi, jelas tujuan perusahaan industri tidak mungkin tercapai, sebab masalah pokok yang dihadapi oleh perusahaan industri, yaitu minimal mempertahankan pasar yang sudah ada, mungkin mencari pasar baru.

Manajemen tidak melakukan sendiri kegiatan-kegiatannya, tetapi selalu dengan menggunakan bantuan dan tenaga orang lain, kare- na itu menajemen harus dapat menggerakkan sekelompok manusia. Kesulitan timbul karena setiap manusia memiliki motif, emosi, aspirasi, rasio serta kepentingan yang berbeda-beda. Sedangkan manajemen harus dapat membawanya kearah pencapaian tujuan yang dikehendaki.

Konsep sumber daya manusia mengacu kepada pandangan holistik aspek manusia melalui pendayagunaan (utilisasi), perencanaan (forcasting), dan pengembangan (development). Utilasi sumber daya manusia merujuk kepada penempatan dan pemanfaatan sumber daya manusia didalamnya termasuk promosi, penilaian, mutasi dan kompensasi. Perencanaan sumber daya manusia meliputi prediksi kebutuhan personil, perencanaan rekruitmen, seleksi, diklat dan pengembangan karir. Pengembangan sumber daya manusia merujuk kepada penyiapan pekerja melalui kegiatan belajar (diklat), pengembangan dan peningkatan kualitas individu (enhancement).

Pengembangan sumber daya manusia mengacu kepada pengembangan pengetahuan, keterampilan, perilaku yang membawa pengaruh kepada peningkatan kinerja, terfokus kepada pertumbuhan dan pengembangan sumber daya manusia melalui program pembelajaran dalam wadah kegiatan pendidikan dan pelatihan sehingga karyawan mampu mengembangkan pengetahuan, kompetensi, keterampilan interpersonal, keterampilan berkomunikasi dan perilaku yang tepat bagi pekerjaan.

Pengembangan sumber daya manusia adalah untuk menciptakan perubahan kinerja karyawan, agar dapat mencapai tujuan organisasi. Fungsi pengembangan sumber daya manusia adalah mempertahankan, meningkatkan, memperbaiki struktur organisasi, menyiapkan pengembangan individu yang difokuskan kepada peningkatan kinerja yang berkaitan dengan tugas, memenuhi kompetensi untuk memenuhi kebutuhan masa kini dan masa datang, fokus kepada peningkatan kinerja yang berkaitan dengan tugas, pengembangan karir, analisa 
kebutuhan individu, optimalisasi pemanfaatan potensi manusia dan efesiensi organisasi, pengembangan pribadi, pengembangan profesional, pengembangan organisasi.

Gaya kepemimpinan dan dalam pemberian motivasi berpengaruh langsung terhadap pengembangan karir pekerja dan bagi pengembangan organisasi, kepemimpinan dan motivasi mempengaruhi secara langsung terhadap prestasi kerja (job performance), perbaikan proses kerja dan kinerja organisasi (job fit and performance), terbentuknya jaringan kerja (net working), kesetiaan terhadap organisasi (organizational loyalty), peluang untuk tumbuh (growth opportunies), evaluasi dan perbaikan organisasi (organization evaluation). Hasibuan (2006:34)

Sumber Daya Manusia (SDM) merupakan sumber daya yang benar - benar dapat dijadikan sebagai strategi yang handal dalam pencapaian tujuan perusahaan, yaitu stategi yang unik untuk memenangkan persaingan. Untuk itu pengelola SDM dalam sebuah perusahaan menjadi sangat penting sehingga harus mendapatkan prioritas utama, jika perusahaan itu ingin maju dan menjadi unggul dalam persaingan bisnis. Pengelolaan SDM sangat berhubungan erat dengan produktivitas SDM itu sendiri. Bagaimana mengelola manusia (SDM) agar mereka menjadi manusia yang berproduktivitas tinggi dan juga bagaimana mengelola perusahaan sebagai wadah manusia dalam mencapai tujuan juga mempunyai produktivitas yang tinggi. Dalam melaksanakan pekerjaan, karyawan tidak lepas dari komunikasi dengan sesama rekan sekerja, dengan atasan dan dengan bawahan. Komunikasi yang baik dapat menjadi sarana yang tepat meminta pentunjuk kepada atasan mengenai pelaksanaan kerja. Melalui komunikasi juga karyawan dapat saling bekerja sama satu sama lain.

Sumber Daya Manusia adalah merupakan salah satu asset utama dan terbesar bagi Institusi, kepemimpinan, pegawailah sebagi pelaksana pelaku aktif dari setiap aktivitas Institusi. Mereka mempunyai pikiran, perasaaan, keinginan dan tidak bersikap pasif pada setiap keadaan apapun. Sesuai dengan perkembangan masyarakat dan perkembangan kepemimpinan di negara kita, paradigma tenaga kepemimpinanpun sudah mengalami perubahan pula, khususnya yang berkaitan dengan sistem dalam lembaga Institusi pendidikan.

Pengertian yang lebih luasnya mengandung unsur demokratis, berorientasi pada sistem dan pedoman yang telah ada melaksanakan kegiatan dan tugas nya, akan tetapi terdapat usaha dalam mencari solusi bagaimana cara memperbaikinya. Sehingga seoarang pemimpin, berkewajiban untuk memberikan contoh yang baik dalam rangka meningkatkan kualitas karyawan.

Kinerja karyawan sangat penting karena berkaitan dengan pengembangan sumber daya manusia yang merupakan kunci keberhasilan suatu organisasi/perusahaan. Sumber daya manusia yang berkualitas akan mampu meningkatkan prestasi kerja karyawan, sehingga kinerjanya pun akan tinggi pula. Karyawan sebagai salah satu komponen di dalam Institusi lembaga pendidikan merupakan unsur penting dalam menjalankan fungsinya di dalam menjalankan tugasnya sebagai orang yang terlibat dan terlihat langsung dalam mengarahkan proses kerja.

Kinerja adalah meningkatkan standar hasil kerja para karyawan dari waktu kewaktu atau hasil kerja yang dapat dicapai oleh seseorang atau sekelompok orang dalam rangka upaya mencapai tujuan organisasi bersangkutan secara legal, tidak melanggar hukum dan sesuai dengan moral ataupun etika.

Kinerja adalah tingkat pelaksanaan tugas yang dapat dicapai oleh seseorang, unit atau divisi dengan menggunakan kemampuan yang ada dan batasan-batasan yang telah ditetapkan untuk mencapai tujuan organisasi.

Seiring dengan berkembangannya ilmu pengetahuan ini yang didasari dengan terciptanya mesin dan peralatan canggih, serta munculnya inovasi - inovasi kerja. Suatu organisasi memerlukan seorang manajer yang mampu menumbuhkan suatu motivasi terhadap kinerja 
karyawan guna mencapai hasil atau tujuan organisasi yang telah ditetapkan.

Karena peran manusia sebagai sumber daya dalam organisasi semakin diyakini kepentingannya, maka semakin mendorong perkembangan ilmu tentang bagaimana mendayagunakan sumber daya manusia tersebut agar mencapai kondisi yang optimal. Berbagai pendekatan manajemen dilakukan dalam mengelola sumber daya manusia tersebut, yang berkembang mengikuti perkembangan dari falsafah manajemen yang sedang dikembangkan pada masa itu. Definisi sumber daya manusia ilmu dan seni atau proses memperoleh, memajukan atau mengembangkan dan memelihara sumber daya manusia yang kompeten sedemikian rupa, sehingga tujuan organisasi dapat tercapai dengan efisiensi dan ada kepuasan pada diri pribadi pribadi yang bersangkutan.

Adanya pemberian motivasi ini berarti telah memberikan kesempatan terhadap karyawan yang menjadi bawahannya sehingga karyawan bisa dan mampu mengembangkan kemampuannya. Motivasi secara sederhana dapat dirumuskan sebagai kondisi ataupun tindakan yang mendorong seseorang untuk melakukan suatu pekerjaan atau kegiatan semaksimal mungkin karyawan untuk berbuat dan berproduksi. Peran motivasi adalah untuk mengintensifkan hasrat dan keinginan tersebut, oleh karena itu dapat disimpulkan bahwa usaha peningkatan semangat kerja seseorang akan selalu terkait dengan usaha memotivasinya sehingga untuk mengadakan motivasi yang baik perlu mengetahui kebutuhan kebutuhan manusia.

Seorang karyawan mungkin melaksanakan pekerjaan yang diberikan kepadanya dengan baik sehingga tujuan perusahaan dapat tercapai bila karyawan dapat melaksanakan tugas dengan baik, tetapi bila tidak maka pimpinan perusahaan perlu mengetahui penyebabnya. Biasanya penurunan semangat dapat terjadi karena kurang disiplin yang disebabkan oleh turunnya motivasi karyawan tersebut untuk itu pimpinan harus dapat memberikan suatu motivasi kepada karyawannya.
Untuk dapat mengembangkan dan membeerdayakan sumberdaya manusia, diperlukan motivasi kerja karyawan. Bahwa seorang karyawan yang tidak puas atas pekerjaannya dapat dimotivasi bekerja lebih baik untuk memperbaiki dirinya.

Maka dengan adanya motivasi yang tinggi dan kinerja yang baik tercermin dari rasa tanggung jawab dan gairah kerja yang menciptakan suatu keinginan untuk bekerja dan memeberikan sesuatu yang terbaik untuk pekerjaannya. Pentingnya motivasi terhadap kinerja menuntut pimpinan organisasi untuk peka terhadap kepentingan karyawan. Pimpinan organisasi melakukan pendekatan tidak hanya terhadap karyawan tetapi juga terhadap keluarga dan lingkungannya sehingga organisasi tahu apa yang menyebabkan karyawan termotivasi dalam bekerja.

Motivasi yang tepat dan baik dapat meningkatkan dan menumbuhkan semangat kerja karyawan dalam bekerja karena dengan adanya gaji atau upah yang sesuai bagi karyawan maka dengan demikian akan tercipta kinerja karyawan yang tinggi.

Perusahaan dapat berkembang merupakan keinginan setiap individu yang berada di dalam perusahaan tersebut, sehingga diharapkan dengan perkembangan tersebut perusahaan mampu bersaing dan mampu mengikuti perkembangan zaman. Karena itu, tujuan yang diharapkan oleh perusahaan dapat tercapai dengan baik. Kemajuan perusahaan dipengaruhi oleh faktor-faktor lingkungan yang bersifat internal dan eksternal. Sejauhmana tujuan perusahaan telah tercapai dapat dilihat dari seberapa besar perusahaan memenuhi tuntutan lingkungannya. Memenuhi tuntutan lingkungan berarti dapat memanfaatkan kesempatan atau mengatasi tantangan atau ancaman dari lingkungan perusahaan tersebut. Perusahaan harus mampu melakukan berbagai kegiatan dalam rangka menghadapi atau memenuhi tuntutan dan perubahan-perubahan di lingkungan perusahaan. 
Niko Resources Ltd Beltway Office Park Building C 3rd Floor adalah perusahaan swasta yang bergerak di bidang pertambangan, juga memiliki tujuan yang sama, yaitu menjadi suatu badan usaha yang dapat berkembang dan mampu mengikuti perkembangan zaman. Untuk dapat mencapai tujuan tersebut tentunya Niko Resources Ltd Beltway Office Park Building C 3rd Floor harus mempunyai karyawan yang memiliki kinerja yang cukup baik, sehingga dengan demikian baik tujuan individu maupun tujuan perusahaan dapat tercapai. Agar kinerja karyawan itu baik tentunya pihak perusahaan harus bisa memberikan suatu motivasi yang baik pula, karena tanpa adanya motivasi kerja yang baik yang diberikan oleh perusahaan maka tidak akan mungkin kinerja seseorang akan baik pula.

Hal ini tentunya harus diimbangi oleh suatu pemberian motivasi kerja yang baik, karena tanpa adanya pemberian motivasi yang baik maka semuanya tidak akan mungkin bisa berjalan dengan baik. Terdapat beberapa indikator dari motivasi yaitu : pengupahan ( Gaji ), keamanan kerja, fasilitas kerja dan penghargaan. Keempat faktor inilah yang dinilai dapat menentukan motivasi seseorang.

Pada Niko Resources Ltd Beltway Office Park Building C 3rd Floor hal yang paling bermasalah dari ketiga faktor tersebut adalah masalah kompensasi, dimana pada saat ini sebagian besar karyawannya merasa keberatan dengan kompensasi yang telah diterimanya. Mereka menganggap bahwa apa yang mereka terima tidak sesuai dengan apa yang telah mereka lakukan bagi perusahaan, karena sekarang pemberian kompensasi diberikan dalam jumlah yang sama bagi semua jabatan sedangkan berat pekerjaan yang mereka lakukan berbeda.

Seperti motivasi kinerja juga memiliki beberapa indikator, yaitu; pendidikan, keterampilan/skill, sikap/etika kerja, tanggung jawab dan lingkungan kerja. Sebagai akibat dari adanya masalah kompensasi tersebut diatas, maka hal ini mengakibatkan pula adanya permasalahan dalam kinerja karyawan yaitu masa- lah sikap. Misalnya, sebagian kecil dari mereka keluar kantor pada saat jam kerja untuk melakukan kegiatan pribadi yang sifatnya bukan untuk pekerjaan kantor.

Kinerja merupakan apa saja yang telah dikerjakan oleh karyawan atau bekerja sebagaimana pekerjaannya dalam perusahaan. Kinerja sangat penting bagi perusahaan untuk menggapai cita-cita perusahaan guna mencapai produktivitas yang meningkat.

Kinerja menurut Anwar Prabu Mangkunegara (2009) dalam bukunya yang berjudul Manajemen Sumber Daya Manusia Perusahaan menyatakan bahwa :Istilah kinerja berasal dari kata Job Performance atau Actual Performance (prestasi kerja atau prestasi sesungguhnya yang dicapai oleh seseorang)Pengertian Kinerja (prestasi kerja) adalah hasil kerja secara kualitas dan kuantitas yang dicapai oleh seorang karyawan dalam melaksanakan tugasnya sesuai dengan tanggungjawab yang diberikan kepadanya”.

Seperti motivasi kinerja juga memiliki beberapa indikator seperti yang dicantumkan oleh Anwar Prabu Mangkunegara dalam bukunya tersebut, yaitu; Pendidikan, Ketrampilan/ skill, Sikap/Etika kerja, Tanggung jawab dan Lingkungan kerja.

Adapun faktor yang mempengaruhi pencapaian kinerja adalah faktor kemampuan(ability) dan faktor motivasi (motivation). Hal ini sesuai dengan pendapat Keith Davis, (1964:484) yang merumuskan bahwa :

Human Performance $=$ Ability + Motivation

Motivation = Attitude+Situation

Ability = Knowledge+Skill

Faktor kemampuan secara psikologis, kemampuan (ability) karyawan terdiri dari kemampuan potensi (IQ) dan kemampuan reality (knowledge + skill) artinya, karyawan yang memiliki IQ di atas rata-rata (IQ 110-120) dengan pendidikan yang memadai untuk jabatannya dan trampil dalam mengerjakan pekerjaan sehari-hari, maka ia akan lebih mudah mencapai kinerja yang diharapkan. Oleh karena itu, karyawan perlu di tempatkan pada pe- 
kerjaan yang sesuai dengan keahliannya ( the right man in the right place, the right man of the right job). Dengan demikian akan menghasikan kualitas kerja yang baik yaitu meliputi ketepatan, ketelitian, keterampilan serta kebersihan. Dan begitu pula akan menghasilkan kuantitas kerja yang baik pula yaitu kerja yang meliputi output rutin maupun non rutin ( exstra ) begitu juga mengenai dengan keandalan kerja yaitu dapat tidaknya diandalkan mengikuti instruksi dan melaksanakan tugas dengan kehati-hatian berinisiatif dan disiplin dan loyalitas terhadap perusahaan, begitu juga dengan Sikap yang berarti sikap perusahaan, sikap karyawan satu sama lain dalam bekerja sama.

Oleh karena itu, pemberian motivasi harus diberikan kepada karyawan agar kinerja karyawan tersebut meningkat sehingga dapat bekerja secara lebih baik lagi agar cita-cita perusahaan dapat tercapai serta meningkatkan produktivitas bagi perusahaan. Hal ini sesuai dengan penelitian yang telah dilakukan oleh Mc Clelland, Edward Murray, Miller dan Gordon W. yang dikutip oleh Hasibuan (2002 : 104) menyimpulkan bahwa ada hubungan yang positif antara motivasi dengan kinerja artinya karyawan yang mempunyai motivasi tinggi cenderung memiliki kinerja yang tinggi, sebaliknya mereka yang kinerjanya rendah dimungkinkan karena motivasinya rendah.

Menjadi pemimpin seharusnya bukan karena faktor kebetulan, akan tetapi seorang pemimpin seyogyanya memiliki visi dan misi, kompetensi, ketegasan dan berintegritas yang tidak diragukan, Seorang pemimpin harus mampu menciptakan lingkungan kerja yang kondusif di kantornya sehingga para karyawan dalam bekerja menjadi optimal, begitu juga dalam pelayanannya tidak tumpang tindih, penyelesaian tugas dan tanggungjawabnya meningkat dan dapat memberikan pelayanan dengan baik secara adminitratif, dan pemimpin juga dapat memberikan motivasi secara langsung sehingga tingkat kedisiplinan karyawan meningkat dan tujuan perusahaan cepat tercapai, upaya ini dilaksanakan melalui peran informasional, relasional, dan desisional yang ia lakukan dengan baik, untuk menjadi seorang pemimpin yang efektif pengalaman kerja bukan satu-satunya jawaban, seorang pemimpin yang kompeten belum tentu akan menjadi pemimpin yang kompeten, oleh karena itu diperlukan pelatihan yang benar-benar intensif dalam menyiapkan seseorang untuk menjadi pemimpin yang kompeten.

Pada Niko Resources Indonesia Ltd hal yang paling bermasalah dari ketujuh faktor tersebut adalah masalah sosial, dimana pada saat ini sebagian besar karyawannya merasa keberatan dengan gaya kepemimpinan yang tidak sesuai yang di harapkan. Mereka menganggap bahwa apa yang mereka berikan tidak sesuai dengan apa yang telah merekalakukan bagi perusahaan, misalkan sekarang pemberian kompensasi diberikan dalam jumlah yang sama bagi semua jabatan sedangkan berat pekerjaan yang mereka lakukan berbeda, ini yang membuat kesenjangan sosial dalam kehidupan karyawan . Observasi melalui quesioner

Seperti gaya kepemimpinan dan motivasi juga memiliki beberapa indikator, yaitu; keinginan untuk hidup (the desire to live), keinginan untuk suatu posisi (the desire for position),keinginan akan kekuasaan (the desire for power), keinginan akan pengakuan (the desire for recognation). Hasibuan (2012:141) Sebagai akibat dari adanya masalah sosial tersebut

Niko Resources Indonesia Ltd adalah perusahaan minyak dan gas Internasional Calgary, Canada yang berbasis independen yang beroperasi di India, Bangladesh, Indonesia, Kurdistan, Trinidad, Madagaskar dan Pakistan. Niko Resources Indonesia Ltd merupakan salah satu perusahaan dengan pertumbuhan tercepat di industri minyak dan gas dengan kapitalisasi pasar sebesar \$ 5 milyar pada perdagangan di bursa efek Toronto dibawah simbol Niko. NikoResources juga merupakan anggota S\&P/ TSX Composite Index dan S\&P/TSX Capped Energy Index. 
(Masalah Motivasi) Penelitian dilakukan dengan jumlah responden 75 orang karyawan PDAM Blora. Dengan menggunakan analisis regresi didapat variabel-variabel yang berpengaruh terhadap variabel yang diamati. Hasil Analisis Regresi dan kualitatif yang telah dilakukan, dihasilkan Iklim Organisasi (X1) dan Motivasi (X2), mempunyai pengaruh yang positif dan signifikan dengan Kinerja Karyawan (Y). Hasil yang diperoleh ternyata Iklim Organisasi di PDAM Blora kondusif, sedangkan motivasi dan kinerja karyawan PDAM Blora tinggi.

(Penelitian Terdahulu) Pengaruh iklim organisasi dan motivasi terhadap kinerja karyawan perusahaan air minum Kabupaten Blora (Risetiawan, Eko Budi (2002) Program Pascasarjana Universitas Diponegoro).

\section{IDENTIFIKASI MASALAH}

Berdasarkan uraian latar belakang yang telah disampaikan diatas ada beberapa masalah yang timbul dapat diidentifikasikan oleh penulis, masalah tersebut adalah sebagai berikut:

1. Fungsi pemimpin yang kurang tegas dan kurang melakukan evaluasi serta tidak efektifnya pemimpin memonitor setiap harinya

2. Pegawai di lingkungan Niko Resources Indonesia Ltd dalam rangka memberikan pelayanan belum dilakukan secara optimal

3. Waktu kerja pokok yang diperlukan untuk memberikan pelayanan internal administrasi tumpang tindih

4. Kurang optimalnya penyelesaian tugas dan tanggung jawab yang harus mereka selesaikan.

5. Kurangnya motivasi kerja karyawan sehingga kinerja menurun dan tidak sesuai dengan harapan perusahaan.

\section{PEMBATASAN MASALAH}

Mengingat aspek gaya kepemimpinan dan motivasi dan pengaruhnya begitu luas maka dalam penelitian ini penulis perlu membatasi yaitu hanya pada pengaruh gaya kepemimpinan dan motivasi terhadap kinerja Karyawan Niko Resources Indonesia Ltd.

1. Yang dimaksud dengan kepemimpinan adalah suatu ilmu yang mengkaji secara komprehensif tentang bagaimana mengarahkan, mempengaruhi,dan mengawasi orang lain untuk mengerjakan tugas sesuai dengan perintah yang direncanakan Irham Fahmi (2013:15).

2. Yang dimaksud Motivasi dalam penelitian ini adalah berasal dari Bahasa latin movere yang berarti dorongan atau menggerakan, motivasi (motivation) dalam manajemen hanya ditunjukan dalam sumber daya manusia umumnya dan bawahan khususnya. Motivasi mempersoalkan bagaimana caranya mengarahkan daya dan potensi sebagai bawahan, agar mau bekerja sama secara produktif berhasil mencapai dan mewujudkan tujuan yang telah ditentukan atau kondisi atau energi yang menggerakan diri karyawan yang terarah atau tertuju untuk mencapai tujuan organisasi perusahaan. Hasibuan (2012:141).

3. Yang dimaksud kinerja dalam penelitian ini adalah bahwa kinerja berasal dari pengertian performance atau sebagai hasil kerja atau prestasi kerja, namun sebenarnya kinerja mempunyai makna yang lebih luas bukan hanya hasil kerja tetapi termasuk bagaimana proses pekerjaan berlangsung, sehingga mempunya hubungan yang kuat dengan tujuan strategis organisasi kepuasan konsumen dan memberikan kontribusi pada ekonomi Armstrong dan Baron dalam Wibowo (2011:7). Dengan demikian kinerja adalah tentang apa yang dikerjakan dan bagaimana cara mengerjakannya.

4. Adapun obyek dalam penelitian ini adalah karyawan Niko Resources Indonesia Ltd.

5. Penelitian ini dilakukan selama 3 (tiga) bulan terhitung mulai Mei sampai dengan Juli 2015. 


\section{PERUMUSAN MASALAH}

Berdasarkan uraian-uraian tersebut di atas sehingga penulis dapat membuat rumusan masalah yang akan diambil dalam penelitian ini adalah:

1. Apakah terdapat pengaruh gaya kepemimpinan terhadap kinerja karyawan pada Niko Resources Indonesia Ltd?

2. Apakah terdapat pengaruh motivasi terhadap kinerja pada karyawan Niko Resources Indonesia Ltd?

3. Apakah gaya kepemimpinan dan motivasi secara simultan berpengaruh signifikan terhadap kinerja keryawan pada Niko Resources Indonesia Ltd?

\section{Kegunaan/Manfaat Penelitian}

Secara formal sebagai menyusun tesis di Universitas Pamulang ini adalah dapat memberikan kontribusi dalam pengembangan ilmu pengetahuan khususnya yang terkait dengan ilmu manajemen bidang sumber daya manusia mengenai pengaruh gaya kepemimpinan dan motivasi terhadap kinerja karyawan. Secara formal sebagai penyusun tesis di Universitas Pamulang ini adalah dapat memberikan kontribusi kepada pihak terkait antara lain:

\section{Manfaat Teoritis}

Bagi Universitas Pamulang dan perpustakaan, sebagai masukan yang bermanfaat bagi sesama rekan mahasiswa, dan hasil penelitian ini juga dapat sebagai bahan pertimbangan bagi peneliti dengan masalah yang sama. Bagi penulis dengan penelitian ini diharapkan dapat diterapkan teori yang telah diperoleh dengan keadaan yang sebenarnya serta untuk memenuhi salah satu persyaratan untuk memperoleh gelar magister manajemen pada universitas pamulang.

\section{Manfaat Praktis}

Bagi Niko Resources Indonesia Ltd, hasil penelitian ini diharapkan dapat bermanfaat sebagai bahan pertimbangan dalam melaksanakan program kegiatan pimpinan dalam memberikan motivasi terhadap kinerja karyawan pada masa yang akan datang.
TINJAUAN PUSTAKA, KERANGKA PEMIKIRAN DAN HIPOTESIS

\section{Pengertian Manajemen}

Manajemen berasal dari kata "to manage" yang berarti mengatur, mengurus atau mengelola. Banyak definisi yang telah diberikan oleh para ahli terhadap istilah manajemen ini. Mary Parker Follet, misalnya, mendefinisikan "manajemen sebagai seni menyelesaikan pekerjaan melalui orang lain. Definisi ini berarti bahwa seorang manajer bertugas mengatur dan mengarahkan orang lain untuk mencapai tujuan organisasi."

Ricky W. Griffin mendefinisikan manajemen sebagai sebuah proses perencanaan, pengorganisasian, pengkoordinasian, dan pengontrolan sumber daya untuk mencapai sasaran (goals) secara efektif dan efesien."Efektif berarti bahwa tujuan dapat dicapai sesuai dengan perencanaan, sementara efisien berarti bahwa tugas yang ada dilaksanakan secara benar, terorganisir, dan sesuai dengan jadwal.

Menurut G.R. Terry manajemen adalah suatu proses atau kerangka kerja, yang melibatkan bimbingan atau pengarahan suatu kelompok orang-orang kearah tujuan-tujuan organisasional atau maksud-maksud yang nyata. "Manajemen juga adalah suatu ilmu pengetahuan maupun seni. Seni adalah suatu pengetahuan bagaimana mencapai hasil yang diinginkan atau dalam kata lain seni adalah kecakapan yang diperoleh dari pengalaman, pengamatan dan pelajaran serta kemampuan untuk menggunakan pengetahuan manajemen."

Menurut Ahli Prof. Eiji Ogawa Manajemen adalah Perencanaan, Pengimplementasian dan Pengendalian kegiatan-kegiatan termasuk system pembuatan barang yang dilakukan oleh organisasi usaha dengan terlebih dahulu telah menetapkan sasaran-sasaran untuk kerja yang dapat disempurnakan sesuai dengan kondisi lingkungan yang berubah.

Menurut Ahli Peter Drucker, Dalam buku The Principles of Management yang ditulis 
oleh pencetus teori bisnis Amerika yang meraih penghargaan Presidential Medal of Freedom ini, manajemen adalah organ yang memiliki banyak tujuan untuk mengelola bisnis serta mengelola manajer dan juga mengelola pekerja dan bekerja.

Menurut Ahli Chaster I Bernard, Manajemen adalah seni dan ilmu, Setelah mengetahui tentang apa itu manajemen dalam sisi pengertian atau definisi, berikutnya Anda juga harus mengetahui tentang fungsi dari manajemen.

Dalam praktenya, fungsi manajemen sangat startegis. Maka dari itu memahami tentang fungsi manajemen sangat dianjurkan bagi siapa saja, terutama bagi mereka yang sedang fokus menempuh mata kuliah manajemen di kampus atau universitas.

Menurut Ahli Ricky W. Griffin, Manajemen sebagai sebuah proses perencanaan, pengorganisasian, pengkoordinasian, dan pengontrolan sumber daya untuk mencapai sasaran (goals) secara efektif dan efesien. Efektif berarti bahwa tujuan dapat dicapai sesuai dengan perencanaan, sementara efisien berarti bahwa tugas yang ada dilaksanakan secara benar, terorganisir, dan sesuai dengan jadwal.

Menurut Ahli Renville Siagian, Manajemen adalah suatu bidang usaha yang bergerak dalam bidang jasa pelayanan dan dikelola oleh para tenaga ahli terlatih serta berpengalaman.

Manajemen menurut James A.F.Stoner, Manajemen adalah suatu proses perencaan, pengorganisasian, leadership, serta pengendalian upaya dari anggota organisasi tersebut serta penggunaan Sumber daya yang tersedia di organisasi tersebut guna mencapai suatu tujuan yang telah ditetapkan organisasi sebelumnya.

Manajemen menurut R.Terry, Manajemen adalah suatu proses unik dan khas yang terdiri atas tindakan-tindakan perencanaan, pengorganisasian, serta penggerakan dan pengendalian yang dilakukan guna menentukan arah serta mencapai tujuan yang telah ditentukan sebelumnya melalui pemanfaatan SDM serta sumber daya lain.

\section{Manajemen Sumber Daya Manusiaa}

Manusia adalah sebagai salah satu unsur dalam organisasi yang bekerja dilingkungan suatu organisasi (disebut juga personil, tenaga kerja, pekerja atau karyawan). Sumber Daya Manusia adalah potensi manusiawi sebagai penggerak organisasi dalam mewujudkan eksitensinya.

Sumber Daya Manusia adalah tenaga kerja yang siap dan mampu serta bersedia memberikan kontribusinya untuk pencapaian tujuan organisasi. Sumber daya manusia atau biasa disingkat SDM adalah potensi yang terkandung dalam diri manusia untuk mewujudkan perannya sebagai mahluk sosial yang adaptif dan transformatif yang mampu mengelola dirinya sendiri serta seluruh potensi yang terkandung di alam menuju tercapainya kesejahteraan kehidupan dalam tatanan yang seimbang dan berkelanjutan. Dalam pengertian praktis sehari-hari, SDM lebih dimengerti sebagai bagian intergral dari sistem yang membentuk suatu organisasi. Sebagai ilmu, SDM dipelajari dalam manajemen sumber daya manusia atau (MSDM)

\section{Gaya Kepemimpinan}

Dalam menghadapi persaingan di era global perusahaan dituntut untuk bekerja lebih efisien dan efektif. Persaingan yang semakin ketat menyebabkan perusahaan dituntut untuk mampu meningkatkan daya saing dalam rangka menjaga kelangsungan hidup perusahaan. Perusahaan merupakan salah satu organisasi yang menghimpun orang-orang yang biasa disebut dengan karyawan atau pegawai untuk menjalankan kegiatan rumah tangga produksi perusahaan. Hampir di semua perusahaan mempunyai tujuan yaitu memaksimalkan keuntungan dan nilai bagi perusahaan, dan juga untuk meningkatkan kesejahteraan pemilik dan karyawan. Karyawan atau pegawai merupakan unsur terpenting dalam menentukan maju mundurnya suatu perusahaan. Untuk mencapai tujuan perusahaan diperlukan karyawan yang 
sesuai dengan persyaratan dalam perusahaan, dan juga harus mampu menjalankan tugastugas yang telah ditentukan oleh perusahaan. Setiap perusahaan akan selalu berusaha untuk meningkatkan kinerja karyawannya, dengan harapan apa yang menjadi tujuan perusahaan akan tercapai. Kemampuan karyawan tercermin dari kinerja, kinerja yang baik adalah kinerja yang optimal. Kinerja karyawan tersebut merupakan salah satu modal

Kepemimpin merupakan salah satu faktor penting karena faktor kepemimpinan dapat memberikan pengaruh yang berarti terhadap kinerja karyawan karena pimpinan yang merencanakan, menginformasikan, membuat, dan mengevaluasi berbagai keputusan yang harus dilaksanakan dalam perusahaan tersebut. Keberhasilaan suatu perusahaan ditunjang oleh peran dari seorang pemimpin dengan gaya kepemimpinan dalam mempengaruhi bawahannya. Untuk mewujudkan gaya kepemimpinan yang efektif diperlukan pemimpin yang berkualitas dan professional yang mampu memotivasi bawahan agar dapat melaksanakan tugasnya sesuai dengan ketentuan yang telah ditetapkan oleh perusahaan tersebut. Setiap pemimpin memiliki gaya kepemimpinan yang berbeda-beda. Dimana gaya pemimpin yang otoriter akan menyebabkan kinerja karyawan terganggu. Sehingga karyawan yang bekerja akan menjadi tertekan dan kurang bersemangat untuk bekerja.

Yang dimaksud dengan kepemimpinan adalah suatu ilmu yang mengkaji secara koprehensif tentang bagaimana mengarahkan, mempengaruhi, dan mengawasi orang lain untuk mengerjakan tugas sesuai dengan perintah yang direncanakan. Irham Fahmi (2013:15).

Gaya kepemimpinan adalah suatu lakon/ peran dalam system organisasi tertentu, karenanya seseorang dalam peran formal belum tentu memiliki ketrampilan kepemimpinan dan belum tentu mampu memimpin. Istilah Kepemimpinan pada dasarnya berhubungan dengan ketrampilan, kecakapan, dan tingkat pengaruh yang dimiliki seseorang; oleh sebab itu kepemimpinan bisa dimiliki oleh orang yang bukan pemimpin.

Indikator Gaya Kepemimpinan

Indikator gaya kepemimpinan yang akan dijadikan pedoman dalam kuisioner di penelitian ini menurut Irham Fahmi (2013:20) yaitu: Bijaksana, Kharismatik, Kesetiakawanan, komunikasi, Motivator dan Sosial.

1) Bijaksana

Sikap bijaksana menyangkut kemampuan dalam mengambil keputusan yang tidak berat sebelah, namun keputusan yang di ambil adalah memikirkan banyak segi dan seimbang (balance)

2) Kharismatik

Kharismatik adalah keadaan atau bakat yang dihubungkan dengan kemampuan yang luar biasa dalam hal kepemimpinan seseorang untuk membangkitkan pemujaan dan rasa kagum dari masyarakat terhadap dirinya atau atribut kepemimpinan yang didasarkan atas kualitas kepribadian individu. Pemimpin kharismatis membawa tanggung-jawab yang besar, dan membutuhkan komitmen jangka panjang dari pemimpin. Seorang pemimpin yang kharismatik memiliki karakteristik yang khas yaitu daya tariknya yang sangat memikat sehingga mampu memperoleh pengikut yang sangat besar dan para pengikutnya tidak selalu dapat menjelaskan secara konkret mengapa orang tertentu itu dikagumi. Pengikutnya tidak mempersoalkan nilai, sikap, dan perilaku serta gaya yang digunakan pemimpin.

3) Kesetiakawanan yang tinggi

Kesetiakawanan yang tinggi menunjukan pemimpin yang memiliki loyalitas tinggi pada sesama rekan kerja bahkan para karyawannya. Kadang kita menemukan pemimpin yang egonya tinggi dan lebih mementingkan diri sendiri tanpa menghiraukan bahwa keputusannya telah memiliki muatan khianat pada yang lainnya. 
4) Komunikasi

Seorang pemimpin memerlukan pemahaman mengenai cara berkomunikasi dengan orang lain terutama dengan para anggota, agar bisa mengatur dan mempengaruhi para anggota untuk mencapai tujuan jangka panjang yang menguntungkan bagi semua pihak yang terlibat.

5) Motivator

Motivasi memberikan daya untuk maju lebih jauh lagi, tanpa motivasi apapun segala yang dikerjakan akan menjadi beban. Seorang pemimpin yang tidak memiliki motivasi positif dalam dirinya hanya akan melemahkan para pengikutnya. Pemimpin yang baik akan menunjukkan motivasi dalam semangat kerja dan komitmen pada tujuan. Dengan motivasi seorang pemimpin akan bisa memelihara determinasi para pengikutnya untuk mencapai tujuan.

6) Sosial yaitu pemimpin yang menaruh belas kasian terhadap orang lain, simpati dan tidak mementingkan diri sendiri.

\section{Motivasi}

Saat ini tidak dapat dipungkiri bahwa globalisasi telah menuntut banyak perubahan, perbaikan serta peningkatan diberbagai bidang. Jika dihubungkan dengan sumber daya manusia perlu ada peningkatan mutu dan kemampuan tenaga kerja agar mampu mandiri dan bersaing. Diantara salah satu aspek yang berkenaan dengan sumber daya manusia yang harus diperhatikan oleh perusahaan adalah motivasi kerja para karyawan (pegawai) yaitu kesediaan pegawai untuk mengerahkan segenap daya dan upayanya untuk perusahaan. Tinggi rendahnya motivasi kerja pegawai akan menentukan tinggi rendahnya tingkat keunggulan bersaing bagi perusahaan. Motivasi kerja pegawai ini perlu ditingkatkan karena akan mempengaruhi kepuasan kerja. Ketika karyawan merasa puas dengan pekerjaanya maka diharapkan kinerja akan meningkat dan tujuan organisasi atau perusahaan dapat tercapai. Perusahaan mempunyai tujuan untuk da- pat hidup berkembang dengan cara mengatasi tantangan baik dari lingkungan eksternal dan internal. Lingkungan yang mempengaruhi jalannya organisasi sifatnya selalu berubah. Oleh karena itu, perusahaan memerlukan suatu pola pengaturan dan pengolahan sumber-sumber daya yang dimilikinya. Perusahaan tidak hanya mengharapkan pegawai yang mampu, cakap dan terampil, tetapi juga pegawai yang memiliki kemauan untuk bekerja giat dan berkeinginan untuk mencapai hasil kerja yang optimal. Kemampuan, kecakapan dan keterampilan pegawai tidak ada artinya bagi perusahaan jika mereka tidak memiliki kemauan untuk bekerja keras dengan mempergunakan kemampuan, kecakapan dan keterampilan yang dimilikinya. Oleh karena itu, motivasi memiliki peranan penting, karena dengan motivasi diharapkan setiap individu pegawai memiliki kemauan untuk bekerja keras serta mencapai prestasi kerja yang tinggi. Motivasi semakin penting karena pimpinan membagikan pekerjaan pada bawahannya untuk dikerjakan dengan baik dan terarah kepada tujuan yang sebelumnya telah ditetapkan. Pimpinan dalam memotivasi pegawai harus menyadari bahwa manusia memiliki kemauan untuk bekerja keras dengan harapan ia akan dapat memenuhi kebutuhan dan keinginan-keinginan dari hasil pekerjaannya. Dalam melaksanakan pekerjaannya, pegawai tidak melaksanankan semua pekerjaannya sendiri, melainkan terkadang dibutuhkan kerjasama yang baik antara sesama pegawai dalam menyelesaikan suatu pekerjaan. Dalam hal ini, pimpinan harus mampu mendorong dan membangkitkan daya gerak (kemauan kerja) pegawainya untuk melaksanakan suatu pekerjaan yang menjadi kewajibannya sehingga mereka termotivasi untuk bekerja sebaik mungkin dan dapat meningkatkan produktivitas kerja mereka. Hal ini perlu diperhatikan karena manusia sebagai tenaga kerja bukan merupakan manusia yang dapat digerakkan begitu saja, melainkan sebagai makhluk hidup yang mempunyai perasaan, kebutuhan, keinginan dan pola pikir sendiri. 
Menurut Hasibuan, (2012:141) motivasi berasal dari kata Latin movere yang berarti dorongan atau menggerakan. Pemberian motivasi dalam manajemen hanya ditunjukan pada sumber daya manusia umumnya dan bawahan khususnya. Pemberian motivasi mempersoalkan bagaimana caranya mengarahkan daya dan pontensi bawahan, agar mau bekerja sama secara produktif berhasil mencapai dan mewujudkan tujuan yang telah ditentukan.

Indikator Motivasi

Menurut Hasibuan (2012: 142) yang harus diperhatikan oleh seorang pimpinan adalah sebagai berikut:

1) Keinginan Untuk Hidup (The Desire to Live) Keinginan untuk hidup merupakan keinginan uatama dari setiap orang, manusia bekerja untuk dapat makan, dan makan untuk dapat melanjutkan hidupnya.

2) Keinginan Untuk Suatu Posisi (The Desire for Position)

Keinginan untuk suatu posisi dengan memiliki sesatu merupakan keinginan manusia yang kedua dan ini salah satu sebab mengapa manusia bekerja.

3) Keinginan Akan Kekuasaan (The Desire for Power)

Keinginan akan kekuasaan merupakan keinginan selangkah diatas keinginan untuk memiliki, yang mendorong orang mau bekerja.

4) Keinginan Akan Pengakuan (The Desire for Recognation)

Keinginan akan pengakuan, penghormatan, dan status sosial, merupakan jenis terakhir dari kebutuhan yang mendorong orang untuk bekerja.

\section{Kinerja}

Kinerja merupakan perilaku nyata yang ditampilkan setiap orang sebagai prestasi kerja yang dihasilkan oleh pegawai sesuai dengan peranannya dalam organisasi. Kinerja pegawai merupakan suatu hal yang sangat penting dalam organisasi untuk mencapai tujuannya. Dalam ber- organisasi, faktor sumber daya manusia merupakan masalah utama disetiap kegiatan yang ada di dalamnya. Karena jika sumber daya manusia yang ada dalam organisasi buruk, maka tujuan organisasi tidak dapat tercapai sebagaimana yang telah direncanakan. Karena peran sumber daya manusia dalam organisasi adalah menentukan keberhasilan organisasi. Semua tindakan yang diambil dalam setiap kegiatan diprakarsai dan ditentukan oleh manusia yang menjadi anggota dalam suatu organisasi. Dalam organisasi pasti sangat membutuhkan adanya faktor sumber daya manusia yang potensial baik pemimpin maupun pegawai pada pola tugas dan pengawasan yang merupakan penentu agar tercapainya tujuan organisasi tersebut. Di sisi lain, organisasi juga harus menjalankan fungsi sosial secara internal dan eksternal untuk menjamin kesejahteraan para anggotanya juga berdampak pada kelangsungan jalannya organisasi. Untuk dapat menghasilkan prestasi kerja yang baik, organisasi harus mempunyai keunggulan kompetitif yang sangat sulit ditiru oleh organisasi lain, yang hanya dapat diperoleh dari pegawai yang inovatif produktif, kreatif selalu bersemangat dan loyal. Ini akan berdampak baik pada kepuasan layanan yang di berikan pegawai kepada masyarakat yang membutuhkan bantuan. Pegawai yang memenuhi kriteria seperti itu hanya akan dimiliki melalui penerapan konsep dan teknik manajemen sumber daya manusia yang tepat dengan semangat kerja yang tinggi serta pemimpin yang efektif dan lingkungan kerja yang mendukung. Dalam hal ini kinerja yang dapat menghasilkan prestasi kerja yang baik adalah kinerja yang optimal, yaitu kinerja yang sesuai standar organisasi dan mendukung tercapainya tujuan organisasi. Organisasi yang baik adalah organisasi yang berusaha meningkatkan kemampuan sumber daya manusianya, karena hal tersebut merupakan faktor kunci untuk meningkaan prestasi kerja pegawai. Tentu terdapat faktor negatif yang dapat menurunkan prestasi kerja pegawai, diantaranya adalah menurunnya keinginan pegawai untuk mencapai tujuan kerja yang efektif, kurangnya ketepatan waktu 
dalam penyelesaian pekerjaan sehingga kurang menaati peraturan, pengaruh yang berasal dari lingkungannya, kurangnya kenyamanan bekerja, teman sekantor yang kurang kompak, kurangnya motivasi untuk meningkatkan semangat kerja dan tidak adanya contoh yang harus dijadikan acuan dalam pencapaian prestasi kerja yang baik. Semua itu merupakan sebab menurunya kinerja pegawai dalam bekerja yang akhirnya sulit untuk meningkatkan prestasi kerja pegawai. Faktor-faktor yang dapat digunakan untuk meningkatkan prestasi kerja diantaranya adalah disiplin kerja, motivasi dan kepuasan kerja.

Menurut Kamus Besar Bahasa Indonesia (2008:333) disiplin ialah kondisi yang merupakan perwujudan sikap mental dan perilaku suatu bangsa ditinjau dari aspek kepatuhan dan ketaatan terhadap ketentuan peraturan dan hukum yang berlaku dalam kehidupan berbangsa dan bernegara. Disiplin dapat hadir sebagai suatu kebiasaan yang akan melekat dalam jiwa individu tersebut jika kesehariannya selalu menaati peraturan yang dalam lingkungan sehari-harinya, baik itu dalam lingkungan keluarga, lingkungan masyarakat, lingkungan kerja dan lingkungan luar. Dalam suatu organisasi seorang pimpinan memerlukan alat untuk komunikasi dengan para pegawainya mengenai tingkah laku para pegawai, dan bagaimana memperbaiki perilaku para pegawai menjadi lebih baik lagi, dan disiplin kerja yang diterapkan merupakan alat komunikasi pimpinan. Karena dengan disiplin dalam bekerja dapat menghasilkan prestasi kerja dalam organisasi. Mangkunegara (2005:61) menyatakan motivasi terbentuk dari sikap (attitude) karyawan dalam menghadapi situasi kerja di perusahaan (situation). Motivasi merupakan kondisi atau energi yang menggerakkan diri karyawan yang terarah atau tertuju untuk mencapai tujuan organisasi perusahaan. Sikap mental karyawan yang pro dan positif terhadap situasi kerja itulah yang memperkuat motivasi kerjanya untuk mencapai kinerja maksimal. Menurut Kamus Besar Bahasa Indonesia (2008:1110) kepuasan kerja merupakan keadaan psikis yang menyenangkan yang dirasakan oleh pekerja dalam suatu lingkungan pekerjaan karena terpenuhinya semua kebutuhan secara memadai. Definisi ini menyimpulkan bahwa kepuasan kerja seseorang dapat diperoleh dari keadaan yang menyenangkan, lingkungan kerja, teman kerja, gaji yang cukup, dan semua kebutuhan dapat diperoleh secara memadai. Kepuasan kerja yang positif juga dapat mempengaruhi prestasi kerja pegawai. Dalam hal ini, penulis akan mencantumkan beberapa hasil penelitian dari peneliti-peneliti terdahulu mengenai pengaruh disiplin kerja, motivasi, dan kepuasan kerja terhadap prestasi kerja, penelitian-penelitian tersebut antara lain: Regina Aditya Reza (2010) melakukan penelitian mengenai pengaruh gaya kepemimpinan, motivasi, dan disiplin kerja terhadap kinerja karyawan PT Sinar Santosa Perkasa. Dan hasilnya adalah menunjukkan bahwa secara parsial variabel-variabel bebas (gaya kepemimpinan, motivasi dan disiplin kerja) mempunyai pengaruh yang signifikan terhadap variabel terikat (kinerja karyawan). Dan secara simultan menunjukkan bahwa variabel-variabel bebas yaitu gaya kepemimpinan, motivasi dan disiplin kerja mempunyai pengaruh yang signifikan secara bersama-sama terhadap variabel terikatnya yaitu kinerja karyawan.

Kinerja dapat diartikan sebagai gambaran mengenai tingkat pencapian pelaksanaan suatu kegiatan atau program atau kebijakan dalam mewujudkan sadaran, tujuan, misi dan visi organisasi yang tertuang dalam rencana strategi suatu organisasi. Beberapa pengertian kinerja yang dikemukakan oleh para penulis:

Indikator Kinerja

Menurut Wibowo (2011:7), Kinerja adalah hasil kerja yang disumbangkan oleh seseorang atau kelompok dalam menunjang tercapainya tujuan organisasi. Adapun Indikator kinerja menurut Wibowo (2011: 1) adalah:

1. Kejujuran

Kejujuran adalah ketulusan hati seorang tenaga kerja dalam melaksanakan tugas dan pekerjaan serta kemampuan untuk tidak menyalahgunakan wewenang yang telah diberikan kepadanya. 
2. Tanggung jawab

Tanggung jawab adalah kesanggupan seorang tenaga kerja dalam menyelesaikan tugas dan pekerjaan yang diserahkan kepadanya dengan sebaik-baiknya dan tepat waktu serta berani membuat risiko atas keputusan yang diambilnya.

3. Kerjasama

Kerjasama adalah kemampuan tenaga kerja untuk bekerja bersama-sama dengan orang lain dalam menyelesaikan suatu tugas dan pekerjaan yang telah ditetapkan sehingga mencapai daya guna dan hasil guna yang sebesar-besarnya.

4. Prakarsa

Prakarsa adalah kemampuan seseorang tenaga kerja untuk mengambil keputusan langkah-langkah atau melaksanakan suatu tindakan yang diperlukan dalam melaksanakan tugas pokok tanpa menunggu perintah dan bimbingan dari atasannya.

5. Keterampilan

Keterampilan adalah segala daya, kesanggupan, kekuatan dan kecakapan/keterampilan teknis maupun sosial yang dimiliki.

\section{Kerangka Berpikir}

Dalam menghadapi tantangan persaingan yang semakin tinggi dan meningkat, setiap perusahaan berusaha untuk tetap bertahan dengan cara meningkatkan kinerja secara efektif dan efisien di setiap elemen yang berada dalam perusahaan tersebut baik elemen internal maupun elemen ekternal. Hal ini dilakukan agar kualitas dari sumber daya yang ada tetap terjaga. Kaitan antara kepemimpinan dan motivasi dengan kinerja karyawan didasarkan atas kenyataan bahwa pimpinan hidup dalam berbagai budaya dan sering kali merupakan instrumen dalam mengkreasi, mengembangkan dan merusak budaya.

\section{Hipotesis Penelitian}

Menurut Sugiyono (2011:159) yang dimaksud dengan hipotesis adalah sebagai berikut:
"Hipotesis diartikan sebagai dugaan sementara terhadap rumusan masalah penelitian."

Berdasarkan perumusan masalah maka dapat dirumuskan hipotesis penelitian Sebagai berikut

\section{Perumusan hipotesis penelitian yaitu:}

1. Diduga gaya kepemimpinan berpengaruh signifikan terhadap kinerja karyawan

2. Diduga motivasi berpengaruh signifikan terhadap kinerja karyawan

3. Diduga gaya kepemimpinan dan motivasi berpengaruh signifikan terhadap kinerja karyawan

\section{METODOLOGI PENELITIAN Tempat dan Waktu Penelitian}

Dalam penelitian ini peneliti mengambil lokasi penelitian pada. Niko Resources Indonesia Ltd Beltway Office Park Building C 3rd yang bergerak di bidang Produksi Minyak Dan Gas Bumi ( Production Sharing Contract) yang beralamat di Jalan TB. Simatupang No.41, Jakarta 12550 .

Penelitian dilaksanakan bulan, May-Juli 2015 hingga tercukupi kebutuhan data dan informasi untuk pelaksanaan tugas akhir. Penelitian ini dilaksanakan secara bertahap diambil dengan pra survei mulai dari pendahuluan, pengiriman kuesioner dan pengolahan data penyusunan, pengajuan proposal, pengajuan surat ijin, konsultasi, dan penyusunan.

\section{Sifat Penelitian}

Sifat penelitian ini adalah deskriptif kuantitatif yaitu penelitian tentang data yang dikumpulkan dan dinyatakan dalam bentuk angka-angka, meskipun juga berupa data kualitatif sebagai pendukungnya, seperti kata-kata atau kalimat yang tersusun dalam angket, kalimat konsultasi atau wawancara antara peneliti dan informan.

\section{Populasi dan Sampel Penelitian}

Menurut Sugiyono (2011:80) mengemukakan definisi populasi adalah wilayah generalisasi 
yang terdiri atas objek atau subjek yang mempunyai kualitas dan karakteristik tertentu yang ditetapkan oleh peneliti untuk dipelajari dan kemudian ditarik kesimpulan. Adapun dalam penelitian ini, yang menjadi populasi adalah karyawan Niko Resources Indonesia Ltd Beltway Office Park Building $\mathrm{C} 3^{\text {rd }}$ yang berjumlah 155 orang.

Adapun pengertian sampel menurut Sugiyono (2011:81), yaitu sebagian dari jumlah dan karakteristik yang dimiliki oleh populasi tersebut.

Untuk menentukan ukuran sampel dari suatu populasi, rumus yang digunakan adalah menurut pendapat Slovin dalam Sugiyono(2011: 86):

$$
n=\frac{N}{1+N(e)^{2}}
$$

\section{Dimana:}

$\mathrm{n}$ = Jumlah sampel

$\mathrm{N}$ = Jumlah populasi

$\mathrm{E}=$ Tingkat kesalahan (error dalam presentase yang dapat ditolerir atas ketidakpastian penggunaan sampel sebagai populasi)

Adapun tingkat kesalahan yang akan digunakan dalam penarikan sampel adalah 5\%. Dengan jumlah populasi $(\mathrm{N})$ sebesar 155 orang, maka dapat diperoleh besarnya sampel sebagai berikut:

$$
\begin{aligned}
& \mathrm{n}=\frac{155}{1+155(0,05)^{2}} \\
& \mathrm{n}=\frac{155}{1+155(0,0025)} \\
& \mathrm{n}=\frac{155}{1.3875} \\
& \mathrm{n}=110.7 \text { dibulatkan menjadi } 111 \text { orang } \\
& \text { Dari perhitungan di atas dapat diketahui }
\end{aligned}
$$
jumlah sampel (n) sebanyak 111 orang.

\section{METODE PENGUMPULAN DATA}

\section{Data Primer}

Data primer adalah data yang diperoleh langsung melalui objek penelitian berupa dokumen-dokumen penting yang berkaitan dengan masalah yang diteliti.
2. Data Sekunder

Data sekunder adalah data yang diperoleh dari sumber-sumber media dan elektronik (bukan dari objek penelitian).

\section{Metode Analisis Data}

1. Analisis Deskriptif

Analisis deskriptif dilakukan untuk mendapatkan deskripsi tentang gaya kepemimpinan dan motivasi dan kinerja dari objek yang diteliti yaitu karyawan Niko Resources Indonesia Ltd yang diperoleh dari hasil pengolahan data kuesioner.

Dalam melakukan analisis deskriptif, digunakan metode frequency analisys. Prequency analisys adalah analisis berdasarkan hasil tabulasi dari instrument penelitian (kuesioner) melalui perhitungan alat analisis statistic deduktif secara sederhana, yaitu dalam bentuk rata-rata nilai, total skor, dan prosentase (\%) dengan menggunakan Microsoft Excel. Hasil frequency analisys ini akan menghasilkan informasi secara statistik tentang gaya kepemimpinan dan motivasi dan kinerja karyawan dari objek yang diteliti yaitu Niko Resources Indonesia Ltd.

2. Uji Instrumen

Agar dapat memperoleh data dari responden dengan baik, kuesioner sebagai instrumen pengumpulan data penelitian harus memenuhi persyaratan validitas dan reliabilitas. Untuk itu kuesioner tersebut harus diuji terlebih dahulu tingkat validitas dan reliabilitas. Mas'ud (2004:54).
a. Uji Validitas
b. Uji Realiabilitas

3. Regresi Berganda

4. Uji Asumsi Klasik Regresi Berganda.

5. Pengujian Hipotesis.

\section{Operasional Variabel Penelitian}

Di dalam opeasionalisasi konsep dalam penelitian, yang perlu dilakukan adalah menentukan faktor-faktor atau keadaan-keadaan yang dicakup dalam konsep dalam penelitian 
ini, konsep-konsep yang akan dioperasionalkan adalah sebagai berikut:

\section{Gaya Kepemimpinan (variabel $\mathrm{X}_{1}$ )} lain:

Gaya Kepemimpinan (Variabel $\mathrm{X}_{1}$ ), antara

1) Bijaksana

Sikap bijaksana menyangkut kemampuan dalam mengabil keputusan yang tidak berat sebelah, namun keputusan yang diambil adalah memikirkan banyak segi dan seimbang (balance)

2) Kharismatik

Kharismatik adalah keadaan atau bakat yang dihubungkan dengan kemampuan yang luar biasa dalam hal kepemimpinan seseorang untuk membangkitkan pemujaan dan rasa kagum dari masyarakat terhadap dirinya atau atribut kepemimpinan yang didasarkan atas kualitas kepribadian individu. Pemimpin kharismatis membawa tanggung-jawab yang besar, dan membutuhkan komitmen jangka panjang dari pemimpin. Seorang pemimpin yang kharismatik memiliki karakteristik yang khas yaitu daya tariknya yang sangat memikat sehingga mampu memperoleh pengikut yang sangat besar dan para pengikutnya tidak selalu dapat menjelaskan secara konkret mengapa orang tertentu itu dikagumi. Pengikutnya tidak mempersoalkan nilai, sikap, dan perilaku serta gaya yang digunakan pemimpin.

3) Kesetiakawanan yang tinggi

Kesetiakawanan yang tinggi menunjukan pemimpin yang memiliki loyalitas tinggi pada sesama rekan kerja bahkan para karyawannya. Kadang kita menemukan pemimpin yang egonya tinggi dan lebih mementingkan diri sendiri tanpa menghiraukan bahwa keputusannya telah memiliki muatan khianat pada yang lainnya.

4) Komunikasi

Seorang pemimpin memerlukan pemahaman mengenai cara berkomunikasi dengan orang lain terutama dengan para anggota, agar bisa mengatur dan mempenga- ruhi para anggota untuk mencapai tujuan jangka panjang yang menguntungkan bagi semua pihak yang terlibat.

5) Motivator

Motivasi memberikan daya untuk maju lebih jauh lagi, tanpa motivasi apapun segala yang dikerjakan akan menjadi beban. Seorang pemimpin yang tidak memiliki motivasi positif dalam dirinya hanya akan melemahkan para pengikutnya. Pemimpin yang baik akan menunjukkan motivasi dalam semangat kerja dan komitmen pada tujuan. Dengan motivasi seorang pemimpin akan bisa memelihara determinasi para pengikutnya untuk mencapai tujuan.

6) Sosial

Sosial yaitu pemimpin yang menaruh belas kasian terhadap orang lain, simpati dan tidak mementingkan diri sendiri.

\section{Motivasi (Variabel $\mathrm{X}_{2}$ )}

Motivasi (Variabel $\mathrm{X}_{2}$ ), antara lain:

a. Keinginan Untuk Hidup (The Desire to Live) Keinginan untuk hidup merupakan keinginan uatama dari setiap orang, manusia bekerja untuk dapat makan, dan makan untuk dapat melanjutkan hidupnya.

b. Keinginan Untuk Suatu Posisi (The Desire for Position)

Keinginan untuk suatu posisi dengan memiliki sesatu merupakan keinginan manusia yang kedua dan ini salah satu sebab mengapa manusia bekerja.

c. Keinginan Akan Kekuasaan (The Desire for Power)

Keinginan akan kekuasaan merupakan keinginan selangkah diatas keinginan untuk memiliki, yang mendorong orang mau bekerja.

d. Keinginan Akan Pengakuan (The Desire for Recognation)

Keinginan akan pengakuan, penghormatan, dan status sosial, merupakan jenis terakhir dari kebutuhan yang mendorong orang untuk bekerja. 


\section{Kinerja (Variabel Y)}

Variabel terikat dalam penelitian ini adalah kinerja karyawan. Adapun indikator-indikator yang digunakan untuk mengukur kinerja adalah:

1. Kejujuran

Kejujuran adalah ketulusan hati seorang tenaga kerja dalam melaksanakan tugas dan pekerjaan serta kemampuan untuk tidak menyalahgunakan wewenang yang telah diberikan kepadanya.

2. Tanggung jawab

Tanggung jawab adalah kesanggupan seorang tenaga kerja dalam menyelesaikan tugas dan pekerjaan yang diserahkan kepadanya dengan sebaik-baiknya dan tepat waktu serta berani membuat risiko atas keputusan yang diambilnya. Tanggung jawab dapat merupakan keharusan pada seorang karyawan untuk melakukan secara layak apa yang telah diwajibkan padanya.

3. Kerjasama

Kerjasama adalah kemampuan tenaga kerja untuk bekerja bersama-sama dengan orang lain dalam menyelesaikan suatu tugas dan pekerjaan yang telah ditetapkan sehingga mencapai daya guna dan hasil guna yang sebesar-besarnya.

4. Prakarsa

Prakarsa adalah kemampuan seseorang tenaga kerja untuk mengambil keputusan langkah-langkah atau melaksanakan suatu tindakan yang diperlukan dalam melaksanakan tugas pokok tanpa menunggu perintah dan bimbingan dari atasannya.

5. Keterampilan

Keterampilan adalah segala daya, kesanggupan, kekuatan dan kecakapan/keterampilan teknis maupun sosial yang dimiliki.

\section{HASIL PENELITIAN DAN PEMBAHASAN}

\section{Hasil Penelitian}

\section{Deskripsi Objek Penelitian}

Populasi yang dijadikan objek penelitian adalah seluruh Karyawan Niko Resources Indonesia Ltd yang berjumlah 155 pegawai. Na- mun karena banyaknya jumlah populasi dan atas keterbatasan waktu, tenaga, dan dana maka peneliti menggunakan teknik sampling terhadap populasi pegawai tersebut sebagai objek penelitian atau sumber data. Dengan menggunakan convidence level 95\% dan margin error 5\%, dengan menggunakan rumus Slovin's formula maka didapat jumlah sampel yang diambil sebesar 111 responden.

\section{Uji Instrumen Penelitian \\ Uji Validitas}

Berikut ini ditampilkan hasil uji validitas masing-masing variabel dari 111 responden.

a. Variabel gaya kepemimpinan (X1)

Berdasarkan tabel 4.5, hasil pengolahan data dapat dilihat bahwa dari 12 item pernyataan yang diajukan mendapatkan hasil yang valid karena nilai rhitung $>$ rtabel.

b. Variabel Motivasi (X2)

Berdasarkan tabel 4.6, hasil pengolahan data dapat dilihat bahwa dari 12 item pernyataan yang diajukan mendapatkan hasil yang valid karena nilai rhitung $>$ rtabel.

c. Variabel Kinerja karyawan (Y) Pada variabel kinerja karyawan (Y) digunakan 12 pernyataan yang disebarkan ke 111 responden dengan hasil sebagai berikut: Berdasarkan tabel 4.7, hasil pengolahan data dapat dilihat bahwa dari 12 item pernyataan yang diajukan mendapatkan hasil yang valid karena nilai rhitung $>$ rtabel.

\section{Uji Reliabilitas}

Berikut ini hasil pengukuran uji reliabilitas dari ketiga variabel yakni gaya kepemimpinan dan motivasi terhadap kinerja karyawan adalah sebagai berikut:

Tabel 4.8 menunjukan nilai Alpha Cronbach atas variabel gaya kepemimpinan sebesar 0,920 , variabel motivasi sebesar 0,746 , dan variabel kinerja karyawan sebesar 0,800 . Dengan demikian dapat ditarik kesimpulan bahwa pernyataan dalam kuesioner ini reliabel karena mempunyai nilai Alpha Cronbach lebih besar 
dari 0,60. Hal ini menunjukan bahwa setiap item pernyataan yang digunakan akan mampu memperoleh data yang konsisten yang berarti bila pernyataan itu diajukan kembali akan diperoleh jawaban yang relatif sama dengan jawaban sebelumnya.

\section{Uji Asumsi Klasik}

a. Uji Normalitas Data

Dari gambar di atas dapat kita lihat bahwa titik-titik persebaran data berada tidak jauh disekitar garis lurus, hal ini menunjukkan bahwa data terdistribusi scara normal.

2. Uji Multikolinearitas

Dari tabel diatas dapat dilihat bahwa tidak ada satupun variabel yang memiliki VIF lebih dari 10 dan tidak ada yang memiliki tolerance value lebih kecil dari 0,1. Jadi dapat disimpulkan dalam penelitian ini bebas dari adanya multikolinearitas dan semua variabel bebas yang dipakai dalam penelitian ini lolos uji gejala multikolinearitas.

3. Uji Heteroskedastisitas

Dari grafik scatterplot di atas, dapat terlihat bahwa tidak ada pola tertentu karena titik menyebar tidak beraturan di atas dan di bawah sumbu 0 pada sumbu Y. Maka dapat disimpulkan bahwa pada model ini tidak terjadi masalah heteroskedastisitas.

\section{Analisis Data}

Sesuai dengan tujuan analisis deskriptif yaitu memberikan gambaran mengenai hasil penelitian secara umum. Sebelum dilakukan analisis statistik terlebih dahulu dilakukan pembobotan terhadap skor masing-masing variabel. Pembobotan ini dilakukan dengan memberikan skor total dengan jumlah item dari variabel yang dibobot, melalui pernyataan yang diberikan penulis dalam kuesioner maka dapat di desktiptifkan setiap variabel yang diteliti.

Metode yang digunakan dalam penelitian ini adalah metode pengukuran skala likert. Di mana pernyataan mengandung lima alternatif jawaban dan bentuk pernyataan telah disusun mengunakan pengukuran skala likert yang diberi bobot, sebagai berikut:

1. Analisis Deskriptif

Dengan melihat nilai rata-rata jawaban responden seperti pada tabel di atas, dapat dijelaskan sebagai berikut:

- Dari 12 butir pernyataan yang diajukan kepada 111 responden, $39.41 \%$ dari seluruh responden rata-rata menjawab sangat setuju.

- Dari 12 butir pernyataan yang diajukan kepada 111 responden, $53.23 \%$ dari seluruh responden rata-rata menjawab setuju.

- Dari 12 butir pernyataan yang diajukan kepada 111 responden, $6.61 \%$ dari seluruh responden rata-rata menjawab ragu-ragu.

- Dari 12 butir pernyataan yang diajukan kepada 111 responden, $0.75 \%$ dari seluruh responden rata-rata menjawab tidak setuju.

- Dari 12 butir pernyataan yang diajukan kepada 111 responden, $0 \%$ dari seluruh responden rata-rata menjawab sangat tidak setuju.

Dari table diatas dapat disimpulkan bahwa gaya kepemimpinan sudah baik dan telah memperhatikan penguasaan prosedur organisasi.

a) Variabel Motivasi (X2)

Dengan melihat nilai rata-rata jawaban responden seperti pada tabel di atas, dapat dijelaskan sebagai berikut:

O Dari 12 butir pernyataan yang diajukan kepada 111 responden, $23.35 \%$ dari seluruh responden rata-rata menjawab sangat setuju.

O Dari 12 butir pernyataan yang diajukan kepada 111 responden, $64.26 \%$ dari seluruh responden rata-rata menjawab setuju. 
O Dari 12 butir pernyataan yang diajukan kepada 111 responden, $11.26 \%$ dari seluruh responden rata-rata menjawab ragu-ragu.

O Dari 12 butir pernyataan yang diajukan kepada 111 responden, $1.13 \%$ dari seluruh responden rata-rata menjawab tidak setuju.

O Dari 12 butir pernyataan yang diajukan kepada 111 responden, $0 \%$ dari seluruh responden rata-rata menjawab sangat tidak setuju.

b) Kinerja karyawan $(\mathrm{Y})$

Dengan melihat nilai rata-rata jawaban responden seperti pada tabel di atas, dapat dijelaskan sebagai berikut:

O Dari 12 butir pernyataan yang diajukan kepada 111 responden, $36.34 \%$ dari seluruh responden rata-rata menjawab sangat setuju.

O Dari 12 butir pernyataan yang diajukan kepada 111 responden, 53\% dari seluruh responden rata-rata menjawab setuju.

O Dari 12 butir pernyataan yang diajukan kepada 111 responden, $8.86 \%$ dari seluruh responden rata-rata menjawab raguragu.

O Dari 12 butir pernyataan yang diajukan kepada 111 responden, $1.8 \%$ dari seluruh responden rata-rata menjawab tidak setuju.

O Dari 12 butir pernyataan yang diajukan kepada 111 responden, $0 \%$ dari seluruh responden rata-rata menjawab sangat tidak setuju.
2. Uji Hipotesis

1) Uji t

Nilai thitung untuk variabel Gaya Kepemimpinan (5.040) lebih besar dibandingkan dengan nilai ttabel $(1,98)$, atau nilai sig. $\mathrm{t}$ untuk variabel gaya kepemimpinan $(0,000)$ lebih kecil dari alpha $(0,05)$. Berdasarkan hasil yang diperoleh maka menolak H0 dan menerima H1 untuk variabel Gaya Kepemimpinan. Dengan demikian, secara parsial variabel Gaya Kepemimpinan berpengaruh positif dan signifikan terhadap kinerja karyawan pada Niko Resources Indonesia Ltd .

a) Pengaruh motivasi terhadap kinerja karyawan

Berdasarkan Tabel 4.13 di atas diperoleh hasil sebagai berikut: Nilai thitung untuk variabel motivasi (3.675) lebih besar dibandingkan dengan nilai ttabel $(1,98)$, atau nilai sig. $\mathrm{t}$ untuk variabel motivasi $(0,000)$ lebih kecil dari alpha $(0,05)$. Berdasarkan hasil yang diperoleh maka menolak H0 dan menerima H1 untuk variabel motivasi. Dengan demikian, secara parsial variabel motivasi berpengaruh positif dan signifikan terhadap kinerja karyawan pada Niko Resources Indonesia Ltd

2) Uji $F$

Berdasarkan Tabel 4.14 di atas diperoleh bahwa nilai Fhitung $(44,392)$ lebih besar dibandingkan dengan nilai Ftabel $(3,08)$, dan sig. $\alpha(0,000 a)$ lebih kecil dari alpha $5 \%(0,05)$. Hal ini mengindikasikan bahwa hasil penelitian menolak H0 dan menerima H1. Dengan demikian secara simultan gaya kepemimpinan dan motivasi berpengaruh signifikan terhadap kinerja karyawan pada Niko Resources Indonesia Ltd . 
3) Regresi Linier Berganda

Pengujian hipotesis ketiga menyatakan bahwa gaya kepemimpinan dan motivasi berpengaruh terhadap kinerja karyawan pada Niko Resources Indonesia Ltd .

Berdasarkan pada Tabel 4.17 di atas, maka persamaan regresi berganda dalam penelitian adalah:

$\hat{\mathrm{Y}}=13.21+0.357 \mathrm{X} 1+0.391 \mathrm{X} 2$

Persamaan regresi berganda ini merupakan model terbaik, karena variabel independen yang dimasukkan dalam persamaan regresi merupakan variabel yang memberikan pengaruh terhadap variabel dependennya. Dari model regresi tersebut dapat dinterpretasikan sebagai berikut:

1) Konstanta sebesar 13.21 menyatakan bahwa jika tidak ada gaya kepemimpinan (X1), motivasi (X2) atau dianggap konstan, maka besarnya kinerja karyawan (Y) adalah sebesar 13.21 atau $13,21 \%$.

2) Koefisien regresi $X 1$ (gaya kepemimpinan) sebesar 0,357 menyatakan bahwa setiap kenaikan 1 unit (karena tanda +) dari gaya kepemimpinan, maka nilai Y (kinerja karyawan) akan bertambah sebesar 0,357 atau $35.7 \%$.

3) Koefisien regresi $X 2$ (motivasi) sebesar 0,391 menyatakan bahwa setiap kenaikan 1 unit (karena tanda + ) dari motivasi, maka nilai Y (kinerja karyawan) akan bertambah sebesar 0,391 atau $39,1 \%$.

4) Koefisien Determinasi (R-Square)

a) X1 terhadap $\mathrm{Y}$

Berdasarkan Tabel 4.16. diperoleh nilai koefisien determinasi sebesar 0.383. Hal ini menunjukkan bahwa kemampuan variabel gaya kepemimpinan menjelaskan pengaruhnya terhadap variabel kinerja karyawan pada Niko Resources Indonesia Ltd adalah sebesar 38.3\%.
Sedangkan sisanya sebesar $61.7 \%$ merupakan pengaruh dari variabel bebas lain yang tidak diteliti dalam penelitian ini.

b) X2 terhadap $Y$

Nilai koefisien determinasi (R2) dipergunakan untuk mengukur besarnya pengaruh variabel bebas motivasi terhadap kinerja karyawan pada Niko Resources Indonesia Ltd .

Berdasarkan Tabel 4.17. diperoleh nilai koefisien determinasi sebesar 0,322 . Hal ini menunjukkan bahwa kemampuan variabel motivasi menjelaskan pengaruhnya terhadap variabel kinerja karyawan pada Niko Resources Indonesia Ltd adalah sebesar 32.2\%. Sedangkan sisanya sebesar $67.8 \%$ merupakan pengaruh dari variabel bebas lain yang tidak diteliti dalam penelitian ini.

c) X1 dan X2 terhadap Y

Nilai koefisien determinasi (R2) dipergunakan untuk mengukur besarnya pengaruh variabel bebas Gaya kepemimpinan dan motivasi terhadap kinerja karyawan pada Niko Resources Indonesia Ltd .

Berdasarkan Tabel 4.18. diperoleh nilai koefisien determinasi sebesar 0,451 . Hal ini menunjukkan bahwa kemampuan variabel Gaya Kepemimpinan dan motivasi menjelaskan pengaruhnya terhadap variabel kinerja karyawan pada Niko Resources Indonesia Ltd adalah sebesar $45.1 \%$. Sedangkan sisanya sebesar $54.9 \%$ merupakan pengaruh dari variabel bebas lain yang tidak diteliti dalam penelitian ini.

\section{Pembahasan}

1. Pengaruh gaya kepemimpinan berpengaruh signifikan terhadap Kinerja karyawan Pengaruh gaya kepemimpinan terhadap kinerja karyawan adalah signifikan karena 
Nilai thitung untuk variabel Gaya Kepemimpinan (5.040) lebih besar dibandingkan dengan nilai ttabel $(1,98)$, atau nilai sig. $\mathrm{t}$ untuk variabel gaya kepemimpinan $(0,000)$ lebih kecil dari alpha $(0,05)$. Berdasarkan hasil yang diperoleh maka menolak H0 dan menerima $\mathrm{H} 1$ untuk variabel Gaya Kepemimpinan. Dengan demikian, secara parsial variabel Gaya Kepemimpinan berpengaruh positif dan signifikan terhadap kinerja karyawan pada Niko Resources Indonesia Ltd .

Berdasarkan hasil penelitian menunjukan bahwa secara statistik ketiga hipotesis yang diajukan terdukung oleh teori sebelumnya. Dari data pada pengujian hipotesis sebelumnya, dapat disimpulkan bahwa hipotesis yang pertama yang mempresentasikan pengaruh positif dan signifikan gaya kepemimpinan terhadap motivasi, terdukung. Dengan demikian cara-cara perilaku pemimpin dalam mengarahkan pengikutnya akan berpengaruh terhadapt motivasi karyawan, sehingga hal ini mendukung penelitian sebelumnya mengenai pengaruh gaya kepemimpinan terhadap motivasi yaitu Sovyia Desianty (2005), Avolio et al. (2004), Durrotun Nafisah (2005) dan Jean Lee (2005).

2. Pengaruh Motivasi berpengaruh signifikan terhadap kinerja karyawan

Pengaruh motivasi terhadap kinerja karyawan adalah signifikan, Nilai thitung untuk variabel motivasi (3.675) lebih besar dibandingkan dengan nilai ttabel $(1,98)$, atau nilai sig. $t$ untuk variabel motivasi $(0,000)$ lebih kecil dari alpha $(0,05)$. Berdasarkan hasil yang diperoleh maka menolak $\mathrm{H} 0$ dan menerima $\mathrm{H} 1$ untuk variabel motivasi. Dengan demikian, secara parsial variabel motivasi berpengaruh positif dan signifikan terhadap kinerja karyawan pada Niko Resources Indonesia Ltd . Hasil pengujian hipotesis kedua dapat disimpulkan bahwa hipotesis kedua dapat diterima dan terdu- kung dengan penelitian sebelumnya. Hal ini berarti keberhasilan dan kinerja seseorang dalam suatu bidang pekerjaan banyak ditentukan oleh tingkat kompetensi, profesionalisme juga komitmen terhadap bidang yang ditekuninya. Sehingga hal ini mendukung penelitian dari Aranya et al. (1982), Sri Trisnaningsih (2003), Budi Maryanto (2008), mengaenai pengaruh positif komitmen terhadap motivasi kerja.

3. Pengaruh gaya kepemimpinan dan motivasi secara simultan berpengaruh signifikan terhadap Kinerja

Gaya Kepemimpinan dan motivasi secara bersama-sama mempunyai kontribusi atau pengaruh yang postif terhadap kinerja karyawan sebesar $45.1 \%$ dan selebihnya 54.9\% dipengaruhi oleh variabel lain yang tidak diteliti dalam penelitian ini. nilai Fhitung lebih besar dari Ftabel sebesar 44,392> 3,08 dengan nilai signifikansi $0,000<0,05$, maka berarti h0 ditolak dan ha diterima, hal ini menunjukan bahwa variabel gaya kepemimpinan dan motivasi secara bersama-sama berpengaruh positif dan signifikan terhadap kinerja karyawan

Untuk hipotesis ketiga yang diajukan yaitu mengenai pengaruh positif dan sinifikan komitmen terhadap kinerja karyawan juga diperoleh kesimpulan bahwa hipotesis dapat diterima dan terdukung. Hal ini berarti motivasi memegang peranan penting bagi peningkatan kinerja yang baik dan pengabaian terhadap komitmen pada organisasi akan menimbulkan kerugian. Motivasi merupakan suatu konsistensi dari wujud keterikatan seseorang terhadap organisasinya. Adanya komitmen yang tepat akan memberikan motivasi yang tinggi dan memberikan dampak yang positif terhadap kinerja suatu pekerjaan. Sehingga mendukung penelitian yang dilakukan oleh McNeeseSmith (2006), Benkhoff (2004), Harrison dan Hubard (2004) dan Sri Trisnaningsih (2007). 
Hal ini mengindikasikan bahwa gaya kepemimpinan seorang pemimpin sangat berpengaruh terhadap kinerja bawahannya, di samping itu untuk mendapatkan kinerja yang baik diperlukan juga adanya pemberian pembelajaran terhadap bawahannya. Sehingga penelitian ini mendukung penelitian sebelumnya yang dilakukan oleh Alberto et al. (2005), Ahmad Fadli (2004), Ari Heryanto (2002), Durrotun Nafisah (2005) dan Sri Trisnaningsih (2007).

\section{PENUTUP}

\section{Kesimpulan}

1. Gaya Kepemimpinan berpengaruh signifikan terhadap kinerja karyawan sebesar $38.3 \%$, sisanya $61.7 \%$ dipengaruhi oleh factor lain.

2. Motivasi berpengaruh signfiikan terhadap kinerja karyawan sebesar $32.2 \%$ dan sisanya $67.8 \%$ dipengaruhi faktor lain.

3. Gaya Kepemimpinan dan motivasi secara bersama-sama mempunyai kontribusi atau pengaruh yang postif terhadap kinerja karyawan sebesar $45.1 \%$ dan selebihnya 54.9\% dipengaruhi oleh variabel lain yang tidak diteliti dalam penelitian ini. nilai Fhitung lebih besar dari Ftabel sebesar 44,392> 3,08 dengan nilai signifikansi $0,000<0,05$, maka berarti h0 ditolak dan ha diterima.

\section{Saran}

1. Kepada pimpinan harus memberikan dorongan kepada pegawainya dalam melaksanakan pekerjaan sesuai dengan tugas dan tanggung jawabnya masing-masing karena dinilai oleh pegawai pimpinan kurang memberikan dukungan.

2. Kepada pihak manajemen Niko Resources Indonesia Ltd untuk melakukan promosi jabatan bagi pegawai yang berpotensi dan mempunyai prestasi kerja yang baik karena dapat meningkatkan kinerja karyawan dalam mencapai tujuan organisasi.

3. Kepada manajemen untuk dapat menerima ide-ide baru dalam menyelesaikan tugas oleh pegawai karena ide-ide baru yang disampaikan dapat memberikan inovasi baru perusahaan dalam meningkatkan kinerja karyawannya.

\section{DAFTAR PUSTAKA}

A.A.Anwar Prabu Mangkunegara. 2011. Manajemen Sumber Daya Manusia. Perusahaan. PT.Remaja Rosda Karya, Bandung

Anwar Prabu Mangkunegara, 2013, Manajemen Sumber Daya Manusia Perusahaan, Remaja Rosdakarya, Bandung.

Anwar Prabu Mangkunegara. 2011. Manajemn Sumber Daya Manusia Perusahaan. Jakarta : PT. Remaja Rosdakarya.

A.A.Anwar Prabu Mangkunegara, (2009). Manajemen Sumber Daya Manusia Perusahaan. Bandung : Rosda.

Arif Rahman, Herman. 2007. Manajemen Sumber Daya Manusia. Yogyakarta: Graha Ilmu

Fahmi, Irham. 2013. Analisis Laporan Keuangan. Bandung: Alfabeta

Handoko, T. Hani. 2012. Manajemen Personalia dan Sumber Daya Manusia. Yogyakarta: BPFE

Handoko, 2010, Manajemen Personalia \& Sumberdaya Manusia, Edisi kedua, BPFE UGM Yogyakarta

Handoko, 2013, Manajemen; Edisi Kedua, Cetakan Ketigabelas, BPFE Yogyakarta.

Hasibuan, Malayu S.P., 2011. Manajemen Sumber Daya Manusia. Bumi Aksara, Jakarta

Harbani, Pasolong.2013.Kepemimpinan Birokrasi. Bandung : CV.Alfabeta

Hasibuan, Malayu S.P., 2011. Manajemen Sumber Daya Manusia. Bumi Aksara, Jakarta.

Hasibuan, Malayu, S.P., 2012.Manajemen Sumber Daya Manusia. Edisi Revisi : PT.Bumi Aksara, Jakarta

Heidjrachman Ranupandojo dan Suad Husnan. 2008. Manajemen Personalia. Yogyakarta: BPFE

Herlambang, Susatyo, 2013, Pengantar Manajemen (cara mudah memahami ilmu mana- 
jemen), Gosyen Publishing, Yogyakarta

Hersey. 2007 Kepemimpinan yang Efektif. Gadjah Mada University Press : Yogyakarta

Husein Umar. 2002. Riset Pemasaran dan Perilaku Konsumen.Jakarta: Gramedia

Imeldi Maria Taroreh, 2015, Analisa Pengaruh Motivasi Kerja, Pelatihan, Kepemimpinan, Komunikasi, dan Kerjasama Tim Terhadap Kinerja pada ST Yoseph di Indonesia, Jurnal Riset Bisnis dan Manajemen Vol 2, No. 4 Ismedia Boe, 2014, Pengaruh Program Pelatihan dan Motivasi Kerja terhadap Kinerja Pegawai Negeri Sipil di Kantor Kepresidenan Republik Timor Leste, E Jurnal Ekonomi dan Bisnis Universitas Udayana, ISSN:2337-3067.

Sugiyono. (2011). Metode Penelitian Kuantitatif Kualitatif dan R\&D. Bandung: Alfabeta

Suwatno. (2011). Manajemen Sumber Daya Manusia. Bandung: Alfabeta.

Malayu S.P Hasibuan. 2008. Dasar-Dasar Perbankan. Jakarta : PT Bumi Aksara

Marihot Tua Efendi. 2012. Manajemen Sumber Daya Manusia. Jakarta : PT. Gramedia Widiasarana Indonesia.

Martoyo, Susilo. Hani, 2012. Manajemen Sumber Daya Manusia. Yogyakarta: BPFE-Yogyakarta

Massofa. 2008. Kepemimpinan dalam Manajemen. Jakarta: PT Rajagrafindo Persada

Nana Sudjana, 2007, Pengantar Ilmu Manajemen, PT. Gramedia Pustaka Utama, Jakarta.

Nawawi, Hadari. 2008. Manajemen Sumber Daya Manusia Untuk Bisnis Yang Kompetitif. Yogyakarta : Gadjah Mada Univesity Press 
